\title{
The Role of Gene Therapy in the Treatments of Type 1 Diabetes Mellitus: a review
}

\author{
Harem Othman Smail \\ Department of Biology, Faculty of science and health, Koya University Koya KOY45, Kurdistan Region - F. R. Iraq \\ Corresponding author \\ harem.othman@koyauniversity.org
}

Manuscript received: 22 July, 2020. Revision accepted: 06 November, 2020. Published: 10 November, 2020.

\begin{abstract}
The main aims of this review were to understand the roles of gene therapy in the treatment and prevention of type 1 diabetes mellitus and I will discuss a brief history, approaches, vector types with the future of diabetes following clinical use. Type 1 diabetes mellitus is a metabolic condition that is identified by insufficient insulin development due to pancreatic damage to beta cells. Control, long life, and diagnosis of these metabolic disorders have become vital sources for many scientists and researchers. After 2000, the latest approaches to molecular medicine were introduced as one of the possible therapeutic options for diabetes type 1 diagnosis. Many genes have been reported as a clinical trial so that damaged genes can be treated and three main approaches shown about 50 years ago are islet transplantation, $\beta$ cell regeneration, and insulin gene therapy to cure and prevent diabetes type. Treating diabetes through gene therapy can promise children and adolescents, but more clinical applications are needed to recognize it as a permanent route.
\end{abstract}

Keywords: Type 1 diabetes mellitus; Gene therapy; $\beta$ cells; Virus vectors and islet.

\section{INTRODUCTION}

Diabetes is one of the metabolic disorders characterized by hyperglycemia due to insulin secretion deficits, insulin action, or both (Smail et al., 2019). Type 1 diabetes mellitus is caused by extreme insulin deficiency secondary to pancreatic beta cell autoimmune damage (Kolodka et al., 1995). The Middle East and North Africa region have the highest average prevalence of diabetes in adults $(10.9 \%)$, while the Western Pacific region has the largest number of adults diagnosed with diabetes and the highest prevalence of diabetes in countries $(37.5 \%)$. In terms of diagnostic criteria, etiology, and genetics, various classes of diabetes mellitus, namely type 1 , type 2 , gestational diabetes, and other types of diabetes mellitus are compared (Kharroubi et al., 2015).

Gene therapy is a new form of molecular medicine that will have a significant impact on human health in the next century (Verma et al., 2000). Visionary scientists had hypothesized almost five decades ago that genetic modification by exogenous DNA could be an effective treatment for inherited human diseases. This strategy of "gene therapy" offered the theoretical advantage that one single treatment would achieve a lasting and possibly curative clinical benefit (Dunbar et al., 2018). Recent gene therapy clinical trials have shown considerable therapeutic benefits and an excellent safety record. They show the long-sought-after potential of gene therapy to provide 'cures' after certain potentially terminal or seriously disabled disorders (Naldini, 2015). To date, approximately 2600 clinical trials on gene therapy have been completed, are underway, or licensed worldwide (Ginn et al., 2018).

Gene therapy is intended to inject genetic material into patient cells to compensate for damaged genes or to include therapeutic transgenes. Gene therapy has advanced from the initial human gene transfer trials to approved clinical therapies over the past three decades (Wang et al., 2020). Modern therapeutic strategies seek to restore the endogenous insulin production rather than traditional insulin injection treatment (Memon and Abdelalim 2020). Differentiation of insulin-producing pancreatic $\beta$ cells from induced pluripotent stem cells (iPSCs) originating from diabetes patients aims to provide autologous cells for cell replacement therapy for diabetes. Present methods, however, generate patient iPSC-derived $\beta$ (SC- $\beta$ ) cells with low in vitro and in vivo function (Maxwell et al., 2020). In several ways, cell replacement therapy for type 1 diabetes (T1D) is a perfect first drug model to follow in the emerging field of regenerative medicine (Brandon et al., 2020).

\section{History of Gene Therapy}

The ideas of gene therapy emerged in the 1960s and early 1970s, while in 1968 Rogers \& Pfuderer demonstrated a proof of concept for virus-mediated gene transfer (Wirth et al., 2013), Development of genetically 
marked cell lines and explanation of the polyoma and SV40 papovavirus mechanisms of cell transformation (Friedmann, 1992). Modern transfection methods were combined with cultured cell selection systems and recombinant DNA technology in the late 1970s. The possibility of successful gene transfer into mammalian cells for gene therapy purposes was generally recognized with the creation of retroviral vectors in the early 1980s (Wolff et al., 1994). However, clinical efficacy in a small-scale clinical trial curing an otherwise fatal immunodeficiency disorder in children could not be demonstrated until the start of the new century (Escors et al., 2010). Pancreatic transplantation, first performed in 1966, exists in the new millennium as a radical treatment for particularly intractable type I diabetes with advanced complications. Gene therapy with molecules like leptin and insulin, still in experimental mode, may one day become a reality (Lakhtakia, 2013). Clinically active islet-free implants began in 1989 which require immunosuppression for long life. For more than 30 years, several encapsulated islet approaches have been ongoing without the definition of a clinically relevant product (Scharp et al., 2014).

\section{Approaches for Gene Therapy in Type 1 of Diabetes}

A cure for type 1 (insulin-dependent) diabetes could be found to replace $\beta$ cells in the generation of surrogate insulin-producing cells (Samson and Chan, 2006). Several different approaches have long been used to seek a cure for diabetes, including islet transplantation, $\beta$ cell regeneration, and insulin gene therapy (Lee et al., 2000).

\section{Islet Transplantation}

The idea of T1D cell replacement therapy remained dormant for 80 years until 1972 when Ballinger and Lacy reversed chemical diabetes by islet transplantation in rats (Shapiro, 2012). Following the success of steroidfree immunosuppression transplantation of fresh human islets (Froud et al., 2005). The inexorable decline in insulin independence following islet transplantation alone (ITA) has raised concerns regarding its clinical utility (Bellin et al., 2012). Allotransplantation of islets into patients with autoimmune type 1 diabetes is a reexposure to autoantigen (Bosi et al., 2001). Although immunosuppression protocols have improved islet transplant outcomes, more research is required to maximize islet availability for transplantation and improve the viability of islets once transplanted (Zarinsefat and Stock, 2020). Islet transplantation in patients with type 1 diabetes can reduce or eliminate the insulin requirement. Exenatide is a long-acting glucagon-like peptide-1 (GLP-1) analog that increases glucose-induced insulin secretion and may increase the mass of $\beta$ cells (Al et al., 2007).
Glucagon responses of islet transplant recipients to hypoglycemia were significantly lower than those observed in control subjects (incremental glucagon [mean $\pm \mathrm{SE}$ ]: $-12 \pm 12$ vs. $64 \pm 22 \mathrm{pg} / \mathrm{ml}$, respectively; $\mathrm{P}<0,05)$, and not significantly different from those of non-transplant type 1 diabetic subjects $(-17 \pm 10 \mathrm{pg} / \mathrm{ml})$ (Paty et al., 2002). A glucose-potentiated arginine test, conducted only in insulin-independent transplant subjects $(n=5)$, showed significant impairments in the glucose-potential slope $(\mathrm{P}<0.05)$ and the maximum response to arginine (ARmax; $P<0.05$ ), a measure of $\beta$ cell secretory capacity. Because ARmax provides an estimate of the functional $\beta$-cell mass, these results suggest that the functional defects observed after islet transplantation may account for a low engrafted $\beta$-cell mass (Rickels et al., 2005).

Moreover, approximately 70 percent of transplanted Type 1 diabetic patients achieved insulin independence (Matsumoto, 2010). By contrast, a clinical review at the BMJ in 2001 anticipated that transplantation of Langerhans islets would be the treatment of choice for most Type 1 patients diabetes by 2010. Islet transplantation is currently an option for a specific group of patients with type 1 diabetes only - those with severe glycaemic lability, recurrent hypoglycemia, and unawareness of hypoglycemia (de et al., 2011). IAK was associated with better glucose control and a slower decrease in eGFR than standard insulin therapy in patients with type 1 diabetes and a functioning kidney transplant (Maanaoui et al., 2020). In this first doubleblind randomized trial, the islet transplant evidence obtained with reparixin does not support the role of CXCR1/2 inhibition in preventing inflammationmediated damage to the islet (Maffi et al., 2020).

\section{Regeneration of $\beta$ Cells}

One goal of regenerative medicine is the instructive incorporation of adult cells into other forms of cells for tissue repair and regeneration (Zhou et al., 2008). Two major efforts are underway to address the $\beta$-cell diabetes deficit: one would produce ex vivo $\beta$-cells that are appropriate for transplantation, and the other would promote $\beta$-cell regeneration in the pancreas (Bonner et al., 2005). The regeneration of pancreatic $\beta$ cells which produce insulin is a key therapeutic strategy for diabetes (Ackeifi et al., 2020). Through adulthood, $\beta$ cell mass increasing the ability to suit peripheral requirements. Insufficient insulin secretion by $\beta$ cells leads to Mellitus diabetes (Teta et al., 2017). Pancreatic insulin-producing $\beta$-cells have a long lifespan, so they replicate very little during a lifetime in healthy conditions (Thorel et al., 2010). Regeneration of pancreatic $\beta$-cell mass following either toxin- or autoimmune-mediated destruction in young rodents is probable, but the degree of recovery declines with age and is incomplete in adult life. Similarly, in children and adolescents with type 1 diabetes, there is histological evidence of islet cell 
neogenesis and regenerative response (Thyssen et al., 2006). Single-cell RNA sequencing (scRNA-seq) of islets identified $\beta$-cell dedifferentiation and dysfunction markers and pathways (Sachs et al., 2020).

Three regeneration modes were established according to the various cellular regeneration origins. In the first mode, the undifferentiated progenitor cells proliferate and differentiate as a self-renewing source in response to injury to repair the lost cell population. The second mode, de-differentiate, and then proliferate the highly defined remaining cells (Wang et al., 2020). Regeneration of lost or dysfunctional islet $\beta$ cells in vivo can fulfill the promise of improved treatment for patients with diabetes. Numerous mitogenic factors have been attempted to achieve this, including gammaaminobutyric acid (GABA) (Yi et al., 2020). Results indicate that curcumin has anti-diabetic properties because of its superior immunomodulatory behavior on T-associated cytokines and immunosuppressive activity on pro-inflammatory cytokines may enhance damage to pancreatic $\beta$ cells (Badr et al., 2020). Proliferation is the primary mechanism of $b$-cell expansion during the early postnatal period to produce sufficient b-cell mass in an organism. However, the proliferation of $b$ cells declines rapidly in early life, and the rate of division of $b$ cells in adults is very low (Guney et al., 2020). However, there is still a great need for new treatments, as TID remains an incurable illness. Natural products, primarily phytochemicals, are a tremendous source of drug lead discovery for diabetes (Apaya et al., 2020). Nevertheless, conventional cell-based research approaches have weaknesses in identifying the precise processes of $\beta$-cell differentiation and transdifferentiation, as well as the related regulatory mechanisms ( $\mathrm{Yu}$ and $\mathrm{Xu}, 2020$ ).

Data cumulated over the past few years suggest that increased $\beta$-cell dedifferentiation plays a crucial role in diabetes progression, shedding new light on potential targets for $\beta$-cell replacement therapy (Zhang et al., 2020). Based on a new understanding of structural and functional dynamics of the bone marrow, a conditioning-free bone marrow transplantation (BMT) with reduced adverse effects opens the possibility of evaluating $\beta$ cell regeneration and euglycemic restoration by inducing allogeneic chimerism in T1DM patients, as shown in a mouse model (Black and Zorina, 2020). A new study now shows that a pharmacological combination of insulin and GLP-1-estrogen conjugate not only decreases the daily requirements for insulin but also improves $\beta$-cell function (De et al., 2020). LIF receptor expression is limited to a subset of transcriptionally isolated human $\beta$ cells with the enhanced proliferative ability (Rosado et al., 2020). Residual $\beta$-cells play a major role in the design of clinical trials: they may not only respond to combination therapies that involve metabolic function stimulants but are also the possible source of new $\beta$-cells (Akirav et al., 2018).

\section{Insulin Gene Therapy}

Insulin treatment options for type 1 and type 2 diabetics have increased since the launch of the insulin analogs in 1996. Insulin therapies are now able to mimic the physiological insulin secretion more closely and thus achieve better glycemic control in diabetes patients (Donner et al., 2019). Gene therapy is one of the diabetes mellitus treatment methods (Ramezani et al., 2019). The two key issues are efficacy and safety in developing insulin-replacement gene therapy as a possible treatment for type 1 diabetes. In addition to using a safe and efficient gene transfer vector, the physiological regulation of the expression of the insulin gene is important (Chen et al., 2011). Insulin gene therapy refers to the targeted expression of insulin in non- $\beta$ cells, the primary therapeutic target being hepatocytes (Handorf et al., 2015). The human insulin gene wrapped in chitosan nanoparticles can be successfully transfected through the gastrointestinal tract into rats (Niu et al., 2008).

Differentiation between ADSC and tissue-specific promoters will improve the therapeutic gene expression. The use of microcarriers can facilitate posttransplantation cell survival and hold potential for longterm cell therapy (Fang et al., 2019). Insulin-producing cell replacement through transplantation shows significant promise but is limited in application due to supply constraints (cadaver-based) and chronic immunosuppression. Important progress has been made over the past decade in tackling these obstacles to broad cell therapy adoption (Latres et al., 2019). The possibility that the risk variants of $\mathrm{BACH} 2$ and CLEC16A could contribute to the development of insulin-triggered type 1 diabetes cannot be excluded in addition to the type 1 diabetes high-risk human leukocyte antigen class II and the class I allele of the insulin gene variable number tandem repeat genotype (Onuma et al., 2019).

Therapeutic studies assess the efficacy of antigenspecific and antigen-nonspecific immune therapies, which also include reconstruction of the damaged betacell mass via islet transplantation, neogenesis, and regeneration, and their combinations (Van et al., 2011). Cells that express insulin and have molecular characteristics that closely resemble bona fide insulinsecreting cells have been produced by the most effective protocols to date; however, these cells are often nonresponsive to glucose, a feature that should be addressed in future protocols (Aguayo et al., 2010). Such beneficial effects of leptin are not underpinned by pancreatic $\beta$-cell regeneration, since circulating insulin levels were undetectable at basal and glucose overload levels (Fujikawa et al., 2010). However, contrary to insulin monotherapy, leptin reduces both lipogenic and cholesterologenic transcription factors and enzymes, and reduces lipids from plasma and tissue (Wang et al., 2010). 


\section{Prevent of Type 1 of Diabetes by Gene Therapy}

Since no existing targeted immunotherapies are currently unable to replace the normal insulin delivery, it is important to have a deep understanding of T1D pathophysiology to prevent T1D development (Kaur, 2020). The study shows that AAT gene therapy decreases cell-mediated autoimmunity, changes the repertoire of $\mathrm{T}$-cell receptors and effectively prevents type 1 diabetes in the NOD mouse model. These findings strongly suggest that AAT gene therapy mediated by rAAV1 may be useful as a novel approach to preventing type 1 diabetes ( $\mathrm{Lu}$ et al., 2006). The data indicate that expression of defensive MHC class II alleles in bone marrow-derived cells provides robust self-tolerance to islet autoantigens and is adequate to prevent recurrence of autoimmune diabetes following islet transplantation (Tian et al., 2007).

Dual activity of heparanase inhibitors / HS replacers as a novel therapeutic class to prevent T1D progression and potentially to mitigate secondary vascular disease developed with long-term T1D (Simeonovic et al., 2020). An independent study showed that the optimal rise of GCs in beta-cells was a compensatory mechanism that prevented high-fat diet-induced betacell failure (Cobo et al., 2020). The role of combination therapy in the prevention of diabetic cardiomyopathy, without forgetting the major contribution of insulin, the preferred medication for the treatment of T1DM (Cieluch et al., 2020). In several chronic diseases, including T1D, a large number of proinflammatory ligands that can signal via RAGE have been implicated. It is therefore unbelievable that RAGE has become a possible therapeutic target for disease treatment and prevention (Le et al., 2020). As an antigen-specific monotherapy, ADi-100 is highly e cacious in reversing elevated hyperglycemia to prevent diabetes, where a promising feature of immune tolerance is the increased apoptosis-inducing BAX content (Alleva et al. ,2020). It has been shown that the formulated autoantigenic islet peptides (GAD65206-220, GAD65536-550, Insulin B923, and C17-A1) used as a tolerogenic vaccine prevented T1D from developing in prediabetic NOD mice (Zhou et al., 2020).

The coxsackievirus $\mathrm{B}$ association with the onset of T1DM has been observed. Accurate trigger detection will contribute to the creation of suitable preventive steps. It can become a foundation for advanced clinical studies to prevent T1DM (Desai et al., 2020). Recognizing that T1D is primarily an autoimmune betacell disorder that only in its final stage progresses to a metabolic syndrome will expand therapeutic options for earlier intervention and improve the prospects for prevention (Desai $n$ et al., 2020). Gene expression with immuno-regulatory capacity may potentially decrease allograft rejection. Recent studies have shown that viral interleukin (IL)-10 can decrease immune response during allotransplantation and is one of the most promising methods for preventing rejection (Jeong et al., 2020).

\section{Vectors for Gene Therapy in Diabetic}

Virus vectors were used as gene transfer vehicles for various applications in preclinical and clinical gene therapy and with the approval of Glybera (Alipogene tiparvovec) as the first gene therapy product as standard medical treatment (Goins et al., 2020). The use of viruses as carriers of genetic products requires a detailed and thorough understanding of viral vectors from viral preparation to clinical use (Afzal et al., 2020). Adenoviral vectors as one of the most common groups used in gene therapy have a high human capacity. They 're not actually integrated into the host genome (Arjmand et al., 2020). In a cerebellar granule cell culture (CGC), treatment with GAD cDNA-containing HSV vectors increases GAD65 and GAD67 expression and GABA release evoked by stimulation (Kanao et al., 2020). The definition of AD, AAV and LV (Shirley et al., 2020) is given on the other hand to competent (RC) viral vectors (De et al., 2020). The advantage of adenoviral vectors over retroviral vectors is that they can transduce both dividing and non-dividing cells and can be prepared in high titers. Adenoviruses can infect insulin-secreting cells, and it has been shown that they can transduce rodent islets (Borkar et al., 2020).

Co-precipitation of calcium phosphate is a simple and cheap method for the genetically modified pancreatic cells being non-viral vectors (Wong et al., 2010). Nearly all of the non-viral vectors used to date are plasmids of expression that were engineered for high expression when transmitted to striated muscle or other cells (Prud et al., 2007). Non-viral HVJ liposomemediated human HGF gene transfer has potential for safe and successful diabetic sensorimotor neuropathy treatment (Kato et al., 2005).

\section{Future gene Therapy in Diabetes:}

In the future, therapeutic strategies should be personalized, given the high variance in genetics and islet autoimmunity among patients (Liu et al., 2020). The recent increase in global stem cell research funding is largely based on the promise to translate scientific understanding of stem cells into regenerative medicine (Wainwright et al., 2006). As the approaches to immunotherapy have remained unsuccessful, transplantation of donor-derived pancreas or islets is the only cure for T1D (Aghazadeh et al., 2017). The urgent need for a much anticipated insulin-secreting substitute for $\beta$-cells led researchers to focus on stem cells (SCs) to produce insulin-secreting $\beta$-cells. SC-based methods have opened up the new horizons to treat T1DM for being more precise and focused therapeutic approaches (Farooq et al., 2019). Replacing pancreatic islets with corpse-derived islets has proven to be a successful functional cure for some T1D patients which allows 
them to be independent of exogenous insulin (Sluch et al., 2019). There was an explosion of interest in developing methods for transplantation to replace the islets lost during natural diabetes development (Emerich, 2002). Clinically appropriate and healthy, the procedure is associated with a low risk of adverse effects (Ahrén, 2011). Clinical trials to improve the engraving, the availability of insulin-producing cell sources and alternative transplant sites are currently under investigation to expand treatment (Bruni et al., 2014). Glucagon-like peptide 1(GLP-1) analogs and alternative insulin pathways, particularly oral (entericgastrointestinal, inhaled) pathways, are now most promising and attractive (Takei et al., 2004).

\section{CONCLUSIONS}

I have come to the following conclusions from the review: The gene therapy production and uses have increased significantly over periodic time. Gene therapy has a reduced role in the secondary complication of diabetes mellitus, and can be a strong option for diabetic patients.

Conflict of interest: The author declares that there are no conflicts of interest concerning the publication of this article.

\section{REFERENCES}

Ackeifi, C., Wang, P., Karakose, E., Fox, J.E.M., González, B.J., Liu, H., Wilson, J., Swartz, E., Berrouet, C., Li, Y. and Kumar, K., 2020. GLP-1 receptor agonists synergize with DYRK1A inhibitors to potentiate functional human $\beta$ cell regeneration. Science Translational Medicine, 12(530).

Afzal, S., Fronza, R. and Schmidt, M., 2020. VSeq-Toolkit: Comprehensive computational analysis of viral vectors in gene therapy. Molecular Therapy-Methods \& Clinical Development.

Aghazadeh, Y. and Nostro, M.C., 2017. Cell therapy for type 1 diabetes: current and future strategies. Current diabetes reports, 17(6), p.37.

Aguayo-Mazzucato, C. and Bonner-Weir, S., 2010. Stem cell therapy for type 1 diabetes mellitus. Nature Reviews Endocrinology, 6(3), pp.139-148.

Ahrén, B., 2011. The future of incretin-based therapy: novel avenues - novel targets. Diabetes, Obesity and Metabolism, 13, pp.158-166.

Akirav, E., Kushner, J.A. and Herold, K.C., 2008. $\beta$-cell mass and type 1 diabetes: going, going, gone?. Diabetes, 57(11), pp.2883-2888.

Al Ghofaili, K., Fung, M., Ao, Z., Meloche, M., Shapiro, R.J., Warnock, G.L., Elahi, D., Meneilly, G.S. and Thompson, D.M., 2007. Effect of exenatide on $\beta$ cell function after islet transplantation in type 1 diabetes. Transplantation, 83(1), pp.24-28.

Alleva, D.G., Rezaee, M., Yip, L., Ren, G., Rosenberg, J., Concepcion, W., Escher, A., Shabahang, S. and Thakor, A.S., 2020. Reversal of Hyperglycemia and Suppression of Type 1
Diabetes in the NOD Mouse with Apoptotic DNA Immunotherapy ${ }^{\mathrm{TM}}\left(\mathrm{ADi}^{\mathrm{TM}}\right)$, ADi-100. Biomedicines, 8(3), p.53.

Apaya, M.K., Kuo, T.F., Yang, M.T., Yang, G., Hsiao, C.L., Chang, S.B., Lin, Y. and Yang, W.C., 2020. Phytochemicals as modulators of $\beta$-cells and immunity for the therapy of type 1 diabetes: Recent discoveries in pharmacological mechanisms and clinical potential. Pharmacological Research, p.104754.

Arjmand, B., Alavi-Moghadam, S., Payab, M., Goodarzi, P., Hosseini, M.S., Tayanloo-Beik, A., Rezaei-Tavirani, M. and Larijani, B., 2020. GMP-Compliant Adenoviral Vectors for Gene Therapy.

Badr, A.M., Sharkawy, H., Farid, A.A. and El-Deeb, S., 2020. Curcumin induces regeneration of $\beta$ cells and suppression of phosphorylated-NF- $\kappa \mathrm{B}$ in streptozotocin-induced diabetic mice. The Journal of Basic and Applied Zoology, 81, pp.1-15.

Bellin, M.D., Barton, F.B., Heitman, A., Harmon, J.V., Kandaswamy, R., Balamurugan, A.N., Sutherland, D.E.R., Alejandro, R. and Hering, B.J., 2012. Potent induction immunotherapy promotes long-term insulin independence after islet transplantation in type 1 diabetes. American Journal of Transplantation, 12(6), pp.1576-1583.

Black, L.A. and Zorina, T., 2020. Genetic profile considerations for induction of allogeneic chimerism as a therapeutic approach for type 1 diabetes mellitus. Drug Discovery Today.

Bonner-Weir, S. and Weir, G.C., 2005. New sources of pancreatic $\beta$-cells. Nature biotechnology, 23(7), pp.857-861.

Borkar, S.S., Wakodkar, S.B., Raghatate, P.S. and Mahapatra, D.K., Gene Therapy: New Therapeutic approach to Diabetes Mellitus. Gene, 1, p.9.

Bosi, E., Braghi, S., Maffi, P., Scirpoli, M., Bertuzzi, F., Pozza, G., Secchi, A. and Bonifacio, E., 2001. Autoantibody response to islet transplantation in type 1 diabetes. Diabetes, 50(11), pp.2464-2471.

Brandon, E.P., Scott, M.J., Zimmerman, M.C. and D'Amour, K.A., 2020. Pluripotent Stem Cell-Derived Islet Replacement Therapy for Diabetes. In Second Generation Cell and Genebased Therapies (pp. 157-181). Academic Press.

Bruni, A., Gala-Lopez, B., Pepper, A.R., Abualhassan, N.S. and Shapiro, A.J., 2014. Islet cell transplantation for the treatment of type 1 diabetes: recent advances and future challenges. Diabetes, metabolic syndrome and obesity: targets and therapy, 7, p.211.

Chen, R., Meseck, M.L. and Woo, S.L., 2001. Auto-regulated hepatic insulin gene expression in type 1 diabetic rats. Molecular Therapy, 3(4), pp.584-590.

Cieluch, A., Uruska, A. and Zozulinska-Ziolkiewicz, D., 2020. Can We Prevent Mitochondrial Dysfunction and Diabetic Cardiomyopathy in Type 1 Diabetes Mellitus? Pathophysiology and Treatment Options. International Journal of Molecular Sciences, 21(8), p.2852.

Cobo-Vuilleumier, N. and Gauthier, B.R., 2020. Time for a paradigm shift in treating type 1 diabetes mellitus: coupling inflammation to islet regeneration. Metabolism, 104, p. 154137 .

De Haan, P., Van Diemen, F.R. and Toscano, M.G., 2020. Viral gene delivery vectors: the next generation medicines for immune-related diseases. Human Vaccines \& Immunotherapeutics, pp.1-8.

De Jesus, D.F. and Kulkarni, R.N., 2020. More is better: combinatorial therapy to restore $\beta$-cell function in diabetes. Nature Metabolism, 2(2), pp.130-131. 
de Kort, H., de Koning, E.J., Rabelink, T.J., Bruijn, J.A. and Bajema, I.M., 2011. Islet transplantation in type 1 diabetes. $B m j, 342$.

Desai, S. and Deshmukh, A., 2020. Mapping of Type 1 Diabetes Mellitus. Current Diabetes Reviews, 16(5), pp.438-441.

Donner, T. and Sarkar, S., 2019. Insulin-pharmacology, therapeutic regimens, and principles of intensive insulin therapy. In Endotext [Internet]. MDText. com, Inc.

Dunbar, C.E., High, K.A., Joung, J.K., Kohn, D.B., Ozawa, K. and Sadelain, M., 2018. Gene therapy comes of age. Science, 359(6372).

Emerich, D.F., 2002. Islet transplantation for diabetes: current status and future prospects. Expert Opinion on Biological Therapy, 2(8), pp.793-803.

Escors, D. and Breckpot, K., 2010. Lentiviral vectors in gene therapy: their current status and future potential. Archivum immunologiae et therapiae experimentalis, 58(2), pp.107-119.

Fang, Q., Zhai, M., Wu, S., Hu, X., Hua, Z., Sun, H., Guo, J., Zhang, W. and Wang, Z., 2019. Adipocyte-derived stem cellbased gene therapy upon adipogenic differentiation on microcarriers attenuates type 1 diabetes in mice. Stem Cell Research \& Therapy, 10(1), pp.1-11.

Farooq, T., Rehman, K., Hameed, A. and Akash, M.S.H., 2019. Stem cell therapy and type 1 diabetes mellitus: treatment strategies and future perspectives. In Tissue Engineering and Regenerative Medicine (pp. 95-107). Springer International Publishing.

Friedmann, T., 1992. A brief history of gene therapy. Nature genetics, 2(2), pp.93-98.

Froud, T., Ricordi, C., Baidal, D.A., Hafiz, M.M., Ponte, G., Cure, P., Pileggi, A., Poggioli, R., Ichii, H., Khan, A. and Ferreira, J.V., 2005. Islet transplantation in type 1 diabetes mellitus using cultured islets and steroid-free immunosuppression: Miami experience. American Journal of Transplantation, 5(8), pp.2037-2046.

Fujikawa, T., Chuang, J.C., Sakata, I., Ramadori, G. and Coppari, R., 2010. Leptin therapy improves insulin-deficient type 1 diabetes by CNS-dependent mechanisms in mice. Proceedings of the National Academy of Sciences, 107(40), pp.17391-17396.

Ginn, S.L., Amaya, A.K., Alexander, I.E., Edelstein, M. and Abedi, M.R., 2018. Gene therapy clinical trials worldwide to 2017: An update. The journal of gene medicine, 20(5), p.e3015.

Goins, W.F., Huang, S., Hall, B., Marzulli, M., Cohen, J.B. and Glorioso, J.C., 2020. Engineering HSV-1 Vectors for Gene Therapy. In Herpes Simplex Virus (pp. 73-90). Humana, New York, NY.

Guney, M.A., Lorberbaum, D.S. and Sussel, L., 2020. Pancreatic $\beta$ cell regeneration: to $\beta$ or not to $\beta$. Current Opinion in Physiology, 14, pp.13-20.

Handorf, A.M., Sollinger, H.W. and Alam, T., 2015. Insulin gene therapy for type 1 diabetes mellitus. Exp clin transplant, 13(Suppl 1), pp.37-45.

Jeong, Y., Park, J.K.H. and Eun, S., 2020, May. Viral Vector Mediated Interleukin-10 Gene Transfer in Skin Allograft. In Transplantation Proceedings. Elsevier.

Kanao-Kanda, M., Kanda, H., Liu, S., Roy, S., Toborek, M. and Hao, S., 2020. Viral Vector-Mediated Gene Transfer of Glutamic Acid Decarboxylase for Chronic Pain Treatment: A Literature Review. Human gene therapy, 31(7-8), pp.405-414.
Kato, N., Nemoto, K., Nakanishi, K., Morishita, R., Kaneda, Y., Uenoyama, M., Ikeda, T. and Fujikawa, K., 2005. Nonviral gene transfer of human hepatocyte growth factor improves streptozotocin-induced diabetic neuropathy in rats. Diabetes, 54(3), pp.846-854.

Kaur, K.K., 2020. Attempting Getting Insulin Independent Immunotherapies in Type 1 Diabetes Mellitus (T1D) in the Pre Stage 1 (Before Islet Autoantibodies). Acta Scientific Paediatrics, 3, pp.01-04.

Kharroubi, A.T. and Darwish, H.M., 2015. Diabetes mellitus: The epidemic of the century. World journal of diabetes, 6(6), p.850.

Kolodka, T.M., Finegold, M., Moss, L. and Woo, S.L., 1995. Gene therapy for diabetes mellitus in rats by hepatic expression of insulin. Proceedings of the National Academy of Sciences, 92(8), pp.3293-3297.

Lakhtakia, R., 2013. The history of diabetes mellitus. Sultan Qaboos University Medical Journal, 13(3), p.368.

Latres, E., Finan, D.A., Greenstein, J.L., Kowalski, A. and Kieffer, T.J., 2019. Navigating two roads to glucose normalization in diabetes: automated insulin delivery devices and cell therapy. Cell metabolism, 29(3), pp.545-563.

Le Bagge, S., Fotheringham, A.K., Leung, S.S. and Forbes, J.M., 2020. Targeting the receptor for advanced glycation end products (RAGE) in type 1 diabetes. Medicinal Research Reviews.

Lee, H.C., Kim, S.J., Kim, K.S., Shin, H.C. and Yoon, J.W., 2000. Remission in models of type 1 diabetes by gene therapy using a single-chain insulin analogue. Nature, 408(6811), pp.483-488.

Liu, B., Xiang, Y., Liu, Z. and Zhou, Z., 2020. Past, present and future of latent autoimmune diabetes in adults. Diabetes/metabolism research and reviews, 36(1), p.e3205.

Lu, Y., Tang, M., Wasserfall, C., Kou, Z., Campbell-Thompson, M., Gardemann, T., Crawford, J., Atkinson, M. and Song, S., 2006. a 1-Antitrypsin gene therapy modulates cellular immunity and efficiently prevents type 1 diabetes in nonobese diabetic mice. Human gene therapy, 17(6), pp.625-634.

Maanaoui, M., Chetboun, M., Kerr-Conte, J., Gmyr, V., Hubert, T., Caiazzo, R., Jannin, A., Le Mapihan, K., Vantyghem, M.C., Hazzan, M. and Pattou, F., 2020. P1672 IMPACT OF ISLET TRANSPLANTATION VERSUS INSULIN ALONE AFTER KIDNEY TRANSPLANTATION IN TYPE 1 DIABETES PATIENTS. Nephrology Dialysis Transplantation, 35(Supplement_3), pp.gfaa142-P1672.

Maffi, P., Lundgren, T., Tufveson, G., Rafael, E., Shaw, J.A., Liew, A., Saudek, F., Witkowski, P., Golab, K., Bertuzzi, F. and Gustafsson, B., 2020. Targeting CXCR1/2 does not improve insulin secretion after pancreatic islet transplantation: a phase 3, double-blind, randomized, placebo-controlled trial in type 1 diabetes. Diabetes Care, 43(4), pp.710-718.

Matsumoto, S., 2010. Islet cell transplantation for Type 1 diabetes. Journal of diabetes, 2(1), pp.16-22.

Maxwell, K.G., Augsornworawat, P., Velazco-Cruz, L., Kim, M.H., Asada, R., Hogrebe, N.J., Morikawa, S., Urano, F. and Millman, J.R., 2020. Gene-edited human stem cell-derived $\beta$ cells from a patient with monogenic diabetes reverse preexisting diabetes in mice. Science Translational Medicine, 12(540).

Memon, B. and Abdelalim, E.M., 2020. Stem cell therapy for diabetes: Beta cells versus pancreatic progenitors. Cells, 9(2), p.283. 
Naldini, L., 2015. Gene therapy returns to centre stage. Nature, 526(7573), pp.351-360.

Niu, L., Xu, Y.C., Dai, Z. and Tang, H.Q., 2008. Gene therapy for type 1 diabetes mellitus in rats by gastrointestinal administration of chitosan nanoparticles containing human insulin gene. World journal of gastroenterology: WJG, 14(26), p.4209.

Onuma, H., Kawamura, R., Tabara, Y., Yamashita, M., Ohashi, J., Kawasaki, E., Imagawa, A., Yamada, Y., Chujo, D., Takahashi, K. and Suehiro, T., 2019. Variants in the BACH2 and CLEC16A gene might be associated with susceptibility to insulin-triggered type 1 diabetes. Journal of Diabetes Investigation, 10(6), pp.1447-1453.

Paty, B.W., Ryan, E.A., Shapiro, A.J., Lakey, J.R. and Robertson, R.P., 2002. Intrahepatic islet transplantation in type 1 diabetic patients does not restore hypoglycemic hormonal counterregulation or symptom recognition after insulin independence. Diabetes, 51(12), pp.3428-3434.

Prud'Homme, G.J., Draghia-Akli, R. and Wang, Q., 2007. Plasmid-based gene therapy of diabetes mellitus. Gene therapy, 14(7), pp.553-564.

Ramezani, K., Gheflat, S., Jajarmi, V., Bandehpour, M. and Kazemi, B., 2019. The Study on Possible Gene Therapy on Diabetics Type I Using Insulin Gene under Control of Heat Shock Promoter in Laboratory Animals. Novelty in Biomedicine, 7(2), pp.45-48.

Rickels, M.R., Schutta, M.H., Markmann, J.F., Barker, C.F., Naji, A. and Teff, K.L., 2005. $\beta$-Cell function following human islet transplantation for type 1 diabetes. Diabetes, 54(1), pp.100-106.

Rosado-Olivieri, E.A., Aigha, I.I., Kenty, J.H. and Melton, D.A., 2020. Identification of a LIF-Responsive, ReplicationCompetent Subpopulation of Human $\beta$ Cells. Cell Metabolism, 31(2), pp.327-338.

Sachs, S., Bastidas-Ponce, A., Tritschler, S., Bakhti, M., Böttcher, A., Sánchez-Garrido, M.A., Tarquis-Medina, M., Kleinert, M., Fischer, K., Jall, S. and Harger, A., 2020. Targeted pharmacological therapy restores $\beta$-cell function for diabetes remission. Nature Metabolism, 2(2), pp.192-209.

Samson, S.L. and Chan, L., 2006. Gene therapy for diabetes: reinventing the islet. Trends in Endocrinology \& Metabolism, 17(3), pp.92-100.

Scharp, D.W. and Marchetti, P., 2014. Encapsulated islets for diabetes therapy: history, current progress, and critical issues requiring solution. Advanced drug delivery reviews, 67, pp.35-73.

Shapiro, A.J., 2012. Islet transplantation in type 1 diabetes: ongoing challenges, refined procedures, and long-term outcome. The review of diabetic studies: RDS, 9(4), p.385.

Shirley, J.L., de Jong, Y.P., Terhorst, C. and Herzog, R.W., 2020. Immune responses to viral gene therapy vectors. Molecular Therapy, 28(3), pp.709-722.

Simeonovic, C.J., Popp, S.K., Brown, D.J., Li, F.J., Lafferty, A.R., Freeman, C. and Parish, C.R., 2020. Heparanase and Type 1 Diabetes. In Heparanase (pp. 607-630). Springer, Cham.

Sluch, V., Swain, D., Whipple, W., Liao, M., Bhoumik, A., Agulnick, A.D. and Rezania, A., 2019, September. CRISPRediting of hESCs allows for production of immune evasive cells capable of differentiation to pancreatic progenitors for future type 1 diabetes therapy. In DIABETOLOGIA (Vol. 62, pp. S6-S7). 233 SPRING ST, NEW YORK, NY 10013 USA: SPRINGER.
Smail, H., Kareem, S. and Abdulkareem, N. (2019) "Comparative Study of the Fingerprint Pattern among Diabetic (Type 1) \& Non-Diabetic Children in Koya City", Journal of Advanced Laboratory Research in Biology, 10(2), pp. 41-47.

Takei, I. and Kasatani, T., 2004. Future therapy of diabetes mellitus. Biomedicine \& pharmacotherapy, 58(10), pp.578581.

Teta, M., Rankin, M.M., Long, S.Y., Stein, G.M. and Kushner, J.A., 2007. Growth and regeneration of adult $\beta$ cells does not involve specialized progenitors. Developmental cell, 12(5), pp.817-826.

Thorel, F., Népote, V., Avril, I., Kohno, K., Desgraz, R., Chera, S. and Herrera, P.L., 2010. Conversion of adult pancreatic $\alpha$ cells to $\beta$-cells after extreme $\beta$-cell loss. Nature, 464(7292), pp.1149-1154.

Thyssen, S., Arany, E. and Hill, D.J., 2006. Ontogeny of regeneration of $\beta$-cells in the neonatal rat after treatment with streptozotocin. Endocrinology, 147(5), pp.2346-2356.

Tian, C., Ansari, M.J.I., Paez-Cortez, J., Bagley, J., Godwin, J., Donnarumma, M., Sayegh, M.H. and Iacomini, J., 2007. Induction of robust diabetes resistance and prevention of recurrent type 1 diabetes following islet transplantation by gene therapy. The Journal of Immunology, 179(10), pp.67626769.

Van Belle, T.L., Coppieters, K.T. and Von Herrath, M.G., 2011. Type 1 diabetes: etiology, immunology, and therapeutic strategies. Physiological reviews, 91(1), pp.79-118.

Verma, I.M., Naldini, L., Kafri, T., Miyoshi, H., Takahashi, M., Blömer, U., Somia, N., Wang, L. and Gage, F.H., 2000. Gene therapy: promises, problems and prospects. In Genes and Resistance to Disease (pp. 147-157). Springer, Berlin, Heidelberg.

Wainwright, S.P., Williams, C., Michael, M., Farsides, B. and Cribb, A., 2006. From bench to bedside? Biomedical scientists' expectations of stem cell science as a future therapy for diabetes. Social science \& medicine, 63(8), pp.2052-2064.

Wang, H., Wei, X., Shi, W., He, J. and Luo, L., 2020. Key Developmental Regulators Suggest Multiple Origins of Pancreatic Beta Cell Regeneration. Zebrafish.

Wang, J.H., Roberts, G.E. and Liu, G.S., 2020. Updates on Gene Therapy for Diabetic Retinopathy. Current Diabetes Reports, 20, pp.1-12.

Wang, M.Y., Chen, L., Clark, G.O., Lee, Y., Stevens, R.D., Ilkayeva, O.R., Wenner, B.R., Bain, J.R., Charron, M.J., Newgard, C.B. and Unger, R.H., 2010. Leptin therapy in insulin-deficient type I diabetes. Proceedings of the national academy of Sciences, 107(11), pp.4813-4819.

Wirth, T., Parker, N. and Ylä-Herttuala, S., 2013. History of gene therapy. Gene, 525(2), pp.162-169.

Wolff, J.A. and Lederberg, J., 1994. An early history of gene transfer and therapy. Human Gene Therapy, 5(4), pp.469-480.

Wong, M.S., Hawthorne, W.J. and Manolios, N., 2010. Gene therapy in diabetes. Self/nonself, 1(3), pp.165-175.

Yi, Z., Waseem Ghani, M., Ghani, H., Jiang, W., Waseem Birmani, M., Ye, L., Bin, L., Cun, L.G., Lilong, A. and Mei, X., 2020. Gimmicks of gamma-aminobutyric acid (GABA) in pancreatic $\beta$-cell regeneration through transdifferentiation of pancreatic $\alpha$-to $\beta$-cells. Cell Biology International, 44(4), pp.926-936.

$\mathrm{Yu}, \mathrm{X} . \mathrm{X}$. and $\mathrm{Xu}, \mathrm{C} . \mathrm{R} ., 2$ 2020. Understanding generation and regeneration of pancreatic $\beta$ cells from a single-cell perspective. Development, 147(7). 
Zarinsefat, A. and Stock, P.G., 2020. Islet vs pancreas transplantation in nonuremic patients with type 1 diabetes. In Transplantation, Bioengineering, and Regeneration of the Endocrine Pancreas (pp. 417-423). Academic Press.

Zhang, J. and Liu, F., 2020, January. The De-, Re-, and transdifferentiation of $\beta$-cells: Regulation and function. In Seminars in Cell \& Developmental Biology. Academic Press.
Zhou, Q., Brown, J., Kanarek, A., Rajagopal, J. and Melton, D.A., 2008. In vivo reprogramming of adult pancreatic exocrine cells to $\beta$-cells. nature, 455(7213), pp.627-632.

Zhou, X., Zhang, S., Yu, F., Zhao, G., Geng, S., Yu, W., Wang, X.Y. and Wang, B., 2020. Tolerogenic vaccine composited with islet-derived multipeptides and cyclosporin A induces pTreg and prevents Type 1 diabetes in murine model. Human vaccines \& immunotherapeutics, 16(2), pp.240-250. 